\title{
Perceptions of Students in Primary Education Department Related to Children's Rights: A Comparative Investigation
}

\author{
Erdem Hareket $^{1} \&$ Meryem Gülhan ${ }^{1}$ \\ ${ }^{1}$ Department of Primary Education, Kırıkkale University, Kırıkkale, Turkey \\ Correspondence: Erdem Hareket, Department of Primary Education, Faculty of Education, Kırıkkale University, \\ Kırıkale, 71450, Turkey. E-mail: erdem.hareket@gmail.com
}

Received: November 13, 2016

Accepted: December 5, 2016 Online Published: December 13, 2016

doi:10.5539/jel.v6n2p41

URL: http://dx.doi.org/10.5539/jel.v6n2p41

"The intellectual perspective that will enlighten the future will arise from the minds of children who will be educated to be aware of their own rights and freedoms..."

\begin{abstract}
This research was performed with the purpose of comparative investigation of perceptions which are related to child rights of the prospective primary school teachers' and pre-school teachers'. The research was designed properly to qualitative research approach. This research was performed with 80 the prospective primary school teachers and pre-school teachers. In determining of the research group, criterion sampling technique was used. In the process of obtaining research data, survey form and semi-structured interview form which is designed for focus group discussions were used. The research data were analyzed with content analysis method. As a result of the research, it was determined that the prospective primary school teachers and pre-school teachers have similar perceptions related to child rights. However, it was determined that the perceptions which are related to child rights of the prospective primary school teachers are more comprehensive than perceptions of the prospective pre-school teachers related to child rights. Morever, it was determined that the both prospective teacher groups have not adequate awareness and consciousness about child rights.
\end{abstract}

Keywords: children, child rights, perceptions related to children's rights, training of child rights, qualitative research, prospective primary school teachers and pre-school teachers

\section{Introduction}

When we stop right now and look back, which life period appears in our mind first? When we want to go on a trip to our past lives, which one of can feel an exciting adventure that can be considered happy in general? Where we are standing right now, in which development period do we realize that our experiences had the bigger importance? Most probably, various answers can be given to these questions. However, there is no doubt that there will be sentences starting with "We were all children once..." and "In our childhood..." among the answers given to any of these questions. Again, among the answers there will probably be narratives starting with "When we were kids..." At this point, the phenomenon of child is an active, creative and social element (Tezcan, 2012); in the first item of Convention on the Rights of Child, which has been formed for the benefits of children, child has been described as every human being until the age of 18. In addition, Tintor (2013) stated that due to their position in the society, children have been perceived as a social group with a special approach. At this point, within the context of education, Quennerstedt A. and Quennerstedt M. (2013) considered the idea of seeing children as adults was a problematic approach and instead of this approach, they thought that it would be a more correct approach to see children as individuals to experience the process of being a human. In addition, it has been stated that the association between these two different ideational approaches is closely related with the phenomenon of rights. From this point of view, at the end of the road that we will set out in the light of the aforementioned problems, it is thought that our childhood will meet us.

Childhood can be defined as the period in which a multi-dimensional development is followed, the basis of values and character is founded, the individual tries to know and explore himself/herself and his/her family, steps into informal and formal education that is wished to last for a lifetime, makes observations about social order and life and as a period which is the basic stop to become a human being of the world who has the skills and qualifications expected from him/her during adulthood. Hareket et al. (2016) stated that childhood is one of the most important and critical periods in which the basis of one's future life is founded in many aspects. From these 
important points of childhood life, it is understood that individuals within this period can need different approaches, they do not have a developmental maturity equal to that of an adult, they have special needs which have to be cared for and fulfilled by many elements, they have to have a healthy life and they should be equipped with the skills and characteristics necessary to adapt to today's conditions. At this point, we can see that with an approach put forward about the concept of children's rights, Akyüz (2012) pointed out that these rights have a content and frame that enables the physical, mental, social, moral and economic development and protection of the child. "Child rights is a universal concept that all the children in the world have from birth in terms of law or morals and which are used to define all the right such as protection against educational, health, sheltering, physical and psychological abuse" (Yıldırım Doğru, 2014). At this point, it is stated that children will take place in the society as individuals as a result of the complicated interactions of natural and social elements of life (Cevher, 2007).

Educational elements that will have a place in a big part of children's familial life and social life should be presented to children with the awareness of the importance of childhood period and with an awareness of the rights children have and the financial possibilities, physical conditions and life conditions presented to children should be suitable in line with children's rights. At this point, it is though that besides the necessity for children to continue their development as individuals who are aware of their own rights, active elements in social life should be aware of children's rights and they should shape their approaches to children on this axis. The 42nd item of Convention on the Rights of Child attracts the attention that the rights given to individuals should be taught to children as well as adults. At this point, Hareket (2015) stated that by giving a qualified child rights education to individuals at an early age, it will be possible to raise children who are aware of their rights, who can defend their rights, who are sensitive for others' rights and who care for others' rights. From a different point of view, it is thought that perceptions about a concept, or the previous experiences within the axis of this concept can influence the quality and efficiency of educational processes. Burlacu (2012) stated that the participation rights of native children in some countries within a limited access education system or an education system that they cannot access at all are violated and these children's views are ignored. Orkodashvili (2013) stated that children friendly schools in primary and secondary education are an example application in increasing children's emotional, physical and psychological welfare and promoting a safe and protective environment, especially for girls. Within this context, it is thought that the perceptions of teachers and prospective teachers about child rights, the form of these perceptions and the adaptation of these perceptions to change and development are also related with the existing school culture. Thus, it is thought that today's prospective primary school and pre-school teachers who are going to be basic elements of the education process are an important factor in forming the behaviors to students, the climate within the classroom and the educational activities to be designed in line with the context of child rights. Clair et al. (2012) stated that in most of the schools, students' being unwilling to do some activities and being afraid of some of the negative consequences caused by teachers as a result of this shows that children's rights are violated by teachers. Thus, it is thought that the perceptions of teachers and prospective teachers on child rights are very important.

At this point, when it is considered that the first person children will see in their formal education lives are pre-school and primary school teachers, it can be understood more clearly how important the perceptions of teachers and prospective teachers have about child rights are. Dündar and Hareket (2016) associated making individuals become aware of child rights in desired ways with the perceptions, attitudes and levels of knowledge of parents, teachers, school managers and student. Within this context, the objective this study was to determine the perceptions of prospective primary school and pre-school teachers, to be able to present an intellectual perspective to new steps to be taken in education of child rights, to new scientific studies about children's rights and child rights education, to studies about developing awareness to child rights within educational environments and to researchers who are interested in the subject.

\section{Methodology}

\subsection{Purpose of Research}

The purpose of this research was to find out the perceptions of prospective teachers studying in undergraduate primary school teaching and pre-school teaching departments related to child rights and to examine these existing perceptions on a comparative basis. Accordingly, this study made examinations about the following research questions:

1) What are the perceptions of prospective primary school teachers related to children's rights?

2) What are the perceptions of prospective pre-school teachers related to children's rights? 
3) What are the similar points of likeness that prospective primary school teachers and pre-school teachers have related to children's rights?

4) What are the different points of perceptions that prospective primary school teachers and pre-school teachers have related to children's rights?

\subsection{Research Approach and Design}

This research was designed suitable for qualitative research approach. Qualitative research approach has been stated to be a method that makes it possible to get more and detailed information on less people and situations (Patton, 2014), a method that enables the reading of the data one by one, and presenting the research results depend on codes and categories (Merriam, 1998). The study had a case study (integrative multiple case) design, which is one of the qualitative research approaches. Yin (2009) stated that as a research method, case study is a method that is used under many circumstances and that enables us to form knowledge about individual, group, organization, social, political and related events. Within this context, situational framework of this study was explained as the participating group members' having an education about child rights within their undergraduate program or having participated in a project related with the subject. At this point, with the thought that it is the most suitable design to find out the perceptions of prospective primary school and pre-school teachers related to child rights and to examine these on a comparative basis, "case study" design, which is suitable for the aforementioned criteria, was used in this research.

\subsection{Research Group}

This research was conducted in the education faculty of a university in Turkey with prospective teachers studying at primary school teaching and pre-school teaching undergraduate programs during the fall term of 2015-2016 Academic Year. 80 participants from each group undergraduate program were included in the study. while the determining the study group, one of the purposive sampling methods, criterion sampling, which is defined by Büyüköztürk et al. (2011) as a method that includes people, events, objects or situations with specific features as observation units, was used. Within this context, the criterion for determining the participants in the study group was studying in either primary school teaching or pre-school teaching undergraduate program, having completed an education about child rights at least at the level of undergraduate or having participated in a project about the subject. Table 1 gives detailed information about participants' genders, undergraduate programs, and the number of being present in the process of obtaining data for the study.

Table 1. The some quantitative information related to participants and the process of obtaining research data

\begin{tabular}{|c|c|c|c|c|c|}
\hline \multirow{5}{*}{$\begin{array}{c}\text { The number of participant in terms of data } \\
\text { collection technique }\end{array}$} & \multicolumn{4}{|c|}{ Department/Sex/Age Range } & \multirow[b]{5}{*}{ Total } \\
\hline & \multicolumn{2}{|c|}{$\begin{array}{l}\text { Primary School Teaching } \\
\text { Undergraduate Program }\end{array}$} & \multicolumn{2}{|c|}{$\begin{array}{c}\text { Pre-school Teaching } \\
\text { Undergraduate Program }\end{array}$} & \\
\hline & \multicolumn{2}{|c|}{ Age range of Participants } & \multicolumn{2}{|c|}{ Age range of Participants } & \\
\hline & \multicolumn{2}{|c|}{$20-23$} & \multicolumn{2}{|c|}{$19-22$} & \\
\hline & Female $(f)$ & Male (f) & Female $(f)$ & Male $(f)$ & \\
\hline The Number of Participant in The Survey & 30 & 10 & 38 & 2 & 80 \\
\hline $\begin{array}{c}\text { The Number of Participant in Focus Group } \\
\text { Discussions }\end{array}$ & 5 & 3 & 6 & 2 & 16 \\
\hline
\end{tabular}

\subsection{Data Collection Tools}

This study was performed by two researchers in the department of primary education. The data were collected through a questionnaire form which was developed by the researchers by using open-ended questions and focus group discussion which is defined by Glesne (2014) as an interview method that enables reaching a specific number of people's point of view at the same time. Patton (2014) stated that adding up answers given to open ended questions made it possible for the researchers to classify previously determined question categories and to reach and understand other people's point of view without prediction. The questionnaire form developed by the researchers and the semi-structured interview form to be used in focus group discussion were examined by three 
experts who were doctors in their field. Following these examinations, the data collection tools took their latest form for application after the process of revision and pilot application.

\subsection{Obtaining Research Data}

The first stage of the process of obtaining research data took place by 80 participants filing out the questionnaire form including 5 open ended questions with the direct participation and control of the researchers to the process. The questionnaire form was completed by the participants in about 45 minutes. After this stage, 8 participants from each of the two participant groups were chosen within the axis of being easily accessible and focus group discussions were made within 125-140 minutes in two different sections with these participant groups on separate days. In focus group discussion, a semi-structured interview form of 7 open-ended questions was used. In focus group discussions, discussions were recorded in line with voice record protocol with the permission of the participants in order to prevent data loss. Voice records of the discussions were transcribed in writing. After this process, the discussion transcriptions were examined by focus group members and participant confirmations were taken in order to increase the validity and reliability of the research data.

\subsection{Analysis Process of Research Data}

Content analysis technique was used in the analysis of qualitative research data obtained from the questionnaire form and focus group discussions. Robson (2015) defined content analysis as coded common sense and purified ways that serve the purpose of describing and explaining earthly concepts. The researchers processed, described and commented on the research data obtained. In order to increase the validity and reliability of the analysis stages of qualitative data, the data were analyzed by two independent researchers other than the researchers of the study. Creswell (2013) stated that including independent researchers in the study in order to analyze the research data from different aspects is an approach to increase the validity of the qualitative research. In addition, inter-coder consistency formula developed by Miles Huberman (1994) was used in order to increase the validity and reliability of the research data. Within the process of coding and forming themes, some minimal differences of opinion occurred between the researchers. Thus, inter-coder reliability value calculation was needed. At the end of this process, inter-coder consistency rate was found as $94 \%$. The detailed information about this process is given in Table 2.

Table 2. Findings related to results of calculation of inter-coders consistency

\begin{tabular}{cc}
\hline Reliability $=$ [Agreement/(Agreement + Divergence) $]$ X 100 & \\
\hline Number of codes arrived at agreement & 60 \\
Number of codes not to be arrived at agreement & 4 \\
Consistency Rate (\%) & 94 \\
\hline
\end{tabular}

The findings of codes and themes formed as a result of the answers of participants to the questionnaire form consisting of open-ended questions and the analysis of the qualitative data obtained from focus group discussions are given in detail in the following section. The findings were analyzed separately for the participant groups of two different undergraduate programs as prospective primary school teachers and pre-school teachers. The research findings obtained as a result of this analysis process were given in detail in different tables. In addition, at the sub sections of tables, direct quotations of the participants who were coded as " $P 1, P 5, P 28, P \ldots$.. were given about the related themes.

\section{Research Findings}

\subsection{Results of the Research Data Obtained from Prospective Primary School Teachers}

The analysis results of the research data obtained from prospective primary school teachers were given under three different themes as "Child rights within the context of personal development and self-sufficiency", "Child rights within the context of legal rights and social life", and "Child rights within the context of basic needs".

The results of the "Child rights within the context of personal development and self- sufficiency" theme are given in Table 3. 
Table 3. The findings related to the child rights within the context of personal development and self-sufficiency theme

\begin{tabular}{lc}
\hline Codes & Frequency \\
\hline Express thoughts comfortably & 24 \\
Think freely & 17 \\
Participate in social activities they want & 16 \\
Make decisions independently on issues related to self & 13 \\
Carry out activities that support their own development & 13 \\
Defend themselves and their rights & 11 \\
Be curious and explore & 11 \\
Make investigation and critical thinking & 10 \\
Ask questions about everything without any fear & 9 \\
Talk when they want & 9 \\
Imagine & 8 \\
Direct to desired profession & 8 \\
\hline Total & $\mathbf{1 4 9}$ \\
\hline
\end{tabular}

When the results in Table 3 about the "Child rights within the context of personal development and self-sufficiency" category are examined, it can be seen that participants mostly expressed these rights as children's rights to participate in social activities they wanted to express their thoughts comfortably and to think freely, to be able to make independent decisions about themselves and to make activities to support their own development. The participants also expressed that children had the right to defend themselves and their rights, to be curious, to explore and research and to question. Some of the direct quotations under this category are as follows:

P21; "All the children are free individuals, thus, every child has the right to express himself.", P24; "I think that children have the right to make decisions about themselves in specific subjects and in specific limits.", P26; "Children have the right to think originally and independently from adults.", P35; "Children are curios, they like to research and they ask questions frequently. I think that these are also children's rights.".

The results of the "Child rights within the context of legal rights and social life" theme are given in Table 4.

Table 4. The findings related to the child rights within the context of legal rights and social life theme

\begin{tabular}{lc}
\hline Codes & Frequency \\
\hline Have qualified education facilities & 41 \\
Get sufficent benefit from health services & 24 \\
Have qualified living conditions & 15 \\
Have a family and grow in a peaceful family environment & 14 \\
Be treated equally with all children & 13 \\
Be accepted in the society as an individual & 11 \\
Live in a society that is respectful and sensitive towards rights & 9 \\
Make friends and spend time with them & 9 \\
Not to be worked at young age & 9 \\
Live in peaceful a World & 9 \\
Have secure social activity areas & 8 \\
\hline Total & $\mathbf{1 6 2}$ \\
\hline
\end{tabular}


When the results in Table 4 are examined, it can be seen that participants mostly expressed these rights as children's rights to have qualified education opportunities, to benefit from health services sufficiently, to have qualified life conditions, to have a family and to grow up in a peaceful family environment and to be treated equally with all the children. The participants also expressed that children had the right to be accepted as individuals in the society and the right to live in a sensitive society. Some of the direct quotations under this category are as follows:

P14; "Getting a qualified education under good circumstances is one of the most basic rights of each child.", P16; "Each child has the right to be born, raised and grown in a comfortable and peaceful environment.", P17;

"All children have the right to benefit sufficiently from the health services given by the government.", P32; "All children need a family with specific characteristics. Children should live in a peaceful family. I mean, I see these as some of the rights children have.".

The results of the "Child rights within the context of basic needs" theme are given in Table 5.

Table 5. The findings related to the child rights within the context of basic needs theme

\begin{tabular}{lc}
\hline Codes & Frequency \\
\hline Play games and have fun & 36 \\
Live & 34 \\
Shelter & 26 \\
Feel being loved and attract attention & 25 \\
Have adequate and balanced nutrition & 25 \\
Protect themselves from all kinds of danger & 21 \\
Be respected by everyone & 20 \\
Sense of belonging & 10 \\
Enjoy their childhood & 8 \\
Be naughty & 8 \\
\hline Total & $\mathbf{2 1 3}$ \\
\hline
\end{tabular}

When the results in Table 5 are examined, it can be seen that participants mostly expressed these rights as children's rights to play and do fun activities, to live, to have shelter, to get love and attention, to be sufficiently and healthily nourished, to be protected from all kinds of bad actions and to be respected. Some of the direct quotations under this category are as follows:

P6; "In my opinion, a child's biggest right is to play games and to have fun. This right of the child is very important for their development.", P11; "Of course, a child's main and most important right is to live.", P8; "All individuals should be respected, thus, the child has the right to be respected by adults and the child should be treated by paying attention to this.", P18; "Having a balanced and sufficient nourishment is one of the rights every child has.", P36; "In my opinion, a child's most necessary and basic right is to be loved and to be cared for.".

\subsection{Results of the Research Data Obtained from Prospective Pre-School Teachers}

The analysis results of the research data obtained from prospective pre- school teachers were given under three different themes as "Child rights within the context of personal development and self-sufficiency", "Child rights within the context of legal rights and social life", and "Child rights within the context of basic needs".

The results of the "Child rights within the context of personal development and self-sufficiency" theme are given in Table 6. 
Table 6. The findings related to the child rights within the context of personal development and self-sufficiency theme

\begin{tabular}{lc}
\hline Codes & Frequency \\
\hline Participate in social activities they want & 13 \\
Make decisions independently on issues related to self & 12 \\
Express opinions comfortably & 11 \\
Think freely & 10 \\
Defend themselves and their rights & 10 \\
Imagine & 8 \\
Be curious and explore & 8 \\
Live as they wish & 7 \\
Have facilities which develop their self-confidence & 7 \\
\hline Total & $\mathbf{8 6}$ \\
\hline
\end{tabular}

When the results in Table 6 are examined, it can be seen that participants mostly expressed these rights as children's rights to participate in the social activity they wanted, to be able to make independent decisions about subjects related to self, to be able to express their thoughts comfortably, to be able to think freely and to be able to defend themselves and their rights. Some of the direct quotations under this category are as follows:

P47; "Children have the right to express their thoughts without being under any pressure.", P63; "I think children should be able to manage their own development. For this, their right to be able to participate in the social activity they want should be taken into consideration.", P41; "Every child has the right to be able to take free decisions about himself/herself and his/her private life. I think parents do not think that every child can have a private life.", P44; "Children have the right to learn their own rights and to defend these rights.".

The results of the "Child rights within the context of legal rights and social life" theme are given in Table 7.

Table 7. The findings related to the child rights within the context of legal rights and social life theme

\begin{tabular}{lc}
\hline Codes & Frequency \\
\hline Have qualified education facilities & 20 \\
Have qualified living possibilities & 16 \\
Get sufficent benefit from health services & 14 \\
Be accepted as an individual in the society & 14 \\
Not to be worked at young age & 13 \\
Have family and grow in peaceful family environment & 10 \\
To be treated equally with all children & 9 \\
Have a good future for their own life & 9 \\
Have a secure social environment & 8 \\
\hline Total & $\mathbf{1 1 3}$ \\
\hline
\end{tabular}

When the results in Table 7 are examined, it can be seen that participants mostly expressed these rights as children's rights to have qualified life conditions, to benefit from health services sufficiently, to be accepted as an individual in the society and not to be made to work in early ages. In addition, the participants stated that children had the right to have a happy family and to grow up in a peaceful family environment, to be treated equally with all children and to have a beautiful future. Some of the direct quotations under this category are as follows: 
P43; "Every child has the right to get a qualified education with equal opportunities.", P63; "It should be remembered in society that children are individuals.", P50; "When they need, children have the right to benefit from state's health services in the best way possible.", P72; "Every child has the right to have qualified living conditions.", P53; "Children have the right not to be made to work in early ages.". P56; "All children have the right of equal opportunities.".

The results of the "Child rights within the context of basic needs" theme are given in Table 8.

Table 8 . The findings related to the child rights within the context of basic needs theme

\begin{tabular}{lc}
\hline Codes & Frequency \\
\hline Protect themselves from all kinds of danger & 32 \\
Live & 26 \\
Play games and have fun & 22 \\
Shelter & 17 \\
Be loved and attract attention & 13 \\
Be respected and valued & 12 \\
Be physically and psychologically well develop & 12 \\
Have adequate and balanced nutriton & 12 \\
Feel secure & 8 \\
\hline Total & $\mathbf{1 5 3}$ \\
\hline
\end{tabular}

When the results in Table 8 are examined, it can be seen that participants mostly expressed these rights as being protected from every kind of bad actions, to live, to play and do fun activities, to have shelter, to get love and attention, to be sufficiently and healthily nourished, to show a healthy development, and to be respected. Some of the direct quotations under this category are as follows:

P69; "Children have the right to be protected from every kind of neglect and abuse.", P70; "Every child has the first right to live.", P58; "In my opinion, playing games, which is known as the job of children, is the most basic right of children.", P78; "Every child has the right to be sheltered in a safe and healthy environment.", P77; "All children should get enough love and care from their families. These are also among the rights of children.".

\section{Discussion and Conclusion}

The objective of this research was to find out the perceptions of prospective teachers studying at the departments of primary school teaching and pre-school teaching undergraduate programs and to examine these in a comparative axis. The results of the study were analyzed separately for both participant groups and the data obtained from the study were grouped under three themes as "Child rights within the context of personal development and self-sufficiency", "Child rights within the context of legal rights and social life", and "Child rights within the context of basic needs". In the following section, the results of the study were discussed in detail for both participant groups.

When the results about the theme of child rights within the context of personal development and self-sufficiency were examined, it was found that prospective primary school teachers stated that children had the right to express their thoughts comfortably, to think freely, to participate in the activity they wanted, to make independent decisions about subjects related to themselves and to do activities that will support their development. About the related category, prospective pre-school teachers mainly stated that children had the rights to participate in the social activity they wanted, to make independent decisions about subjects related to them and to express their thoughts comfortably. At this point, it can be seen that both participant groups similarly stated that children had the rights to participate in the social activity they wanted, to make independent decisions about subjects related to them and to express their thoughts comfortably. When the results about the theme of child rights within the context of legal rights and social life were examined, it was found that prospective primary school teachers mostly stated that children had the right to have qualified education opportunities, to benefit from health services sufficiently, and to have qualified life conditions. About the related category, prospective pre-school teachers mainly stated that children had the rights to have qualified education 
opportunities and qualified life conditions, to benefit from health services sufficiently and to be accepted as an individual in the society. At this point, it can be seen that both participant groups similarly stated that children had the rights to have sufficiently qualified education opportunities and good living conditions and to be able to access qualified health services at a satisfactory level. When the results about the theme of child rights within the context of basic needs were examined, it was found that prospective primary school teachers mostly stated that children had the right to play and do fun activities, to live, to have shelter, to get love and attention, to be sufficiently and healthily nourished, and to be protected from all kinds of bad actions. About the related category, prospective pre-school teachers mainly stated that children had the rights to be protected from all kinds of bad actions, to live, to play and to do fun activities and to have shelter. At this point, it can be seen that both participant groups similarly stated that children had the rights to play and have fun, to live, to have shelter, and to be protected from all kinds of bad actions. When this study was compared with other studies which had similar characteristics from various respects such as content, subject and research group, it can be seen that studies are mostly conducted with parents, teachers, prospective teachers and students with different education levels. In addition, it can be seen that studies were mostly studies of attitude about child rights and different approaches were brought to the subject in terms of the elements of education.

In a study conducted by Dinç (2015) to find out the views of parents who had children between the ages 5 and 6 about child rights, child rights education applications and the problems encountered in these applications, it was found that parents stated that children had the rights to express their thoughts, to choose and to decide, and to do what they want to do as long as they do not hurt others. In addition, it was found that parents wanted to be educated and their children to be educated about child rights in pre-school education institutions. In a study conducted by Yaşar Ekici (2014) to examine the attitudes of prospective teachers about child rights, it was concluded that the undergraduate program studied or graduated from influenced prospective teachers' attitudes about child rights. When the results of this study are examined, it can be seen that both prospective teacher groups had similar perceptions about child rights; however, different answers were found in some categories about child rights and the repetitions of codes formed about child rights revealed variations. Similar to the results of the present study, a study conducted by Kepenekçi and Baydık (2009) to find out the attitudes of prospective teachers for mentally retarded children about child rights showed that the attitudes of the students in the aforementioned program about child rights did not differ from the attitudes of prospective pre-school teachers; however, the attitudes of this group were found to be more negative than the attitudes of the group in primary school teaching. At this point, it can be said that the attitudes and perceptions of students studying in the undergraduate programs of pre-school teaching should be developed.

The results of the study conducted by Uçuş and Şahin (2012) showed that in general, teachers and school administrators did not have sufficient information about child rights and did not make any direct applications about child rights. In the present study, it is thought that prospective teachers in both groups do not have sufficient information and perception levels in some fields about the participation and development rights of the child. At this point, it can be said that the results of the study is similar to the results of this study.

In a research conducted by Demirezen, Altıkulaç and Akhan (2013) to find out the perceptions of primary school students about child rights, it was found that students' perceptions about child rights focused on games and fun, education, living, being raised, being cared for, being protected, being loved and the freedom to express their thoughts. In addition, it was found that the students were very sensitive about rights on having fun and playing; however, they did not have enough information about some rights such as being protected, being educated, freedom, thought and living, which were in United Nations Convention for Child Rights. The results of the study by Karaman Kepenekçi and Nayır (2012) showed that teachers were insufficient in events related with child abuse and neglect and did not have enough information about what they had to do and the researchers emphasized that mainly families, teachers and students should be educated about child abuse and neglect. At this point, teachers' and prospective teachers' level of information about child rights and their perceptions about the subject are important issues in terms of the quality of education processes.

In a research which is conducted by Ersoy (2011), which was conducted to find out the perceptions of primary school students about child rights, it was found that some students had misperceptions about their own rights and perceived children's interests and wants as their rights. As a result of this study, it is thought that prospective teachers have perceptions that can be developed about child rights. Within this context, in relation to the results of the study above, it can be said that when it is considered that the people who will make children become aware of their rights are today's prospective teachers, it can be said that the results obtained are in accordance with the desired results. 
In a study performed by Neslitürk and Ersoy (2007) on prospective pre-school teachers, it was concluded that prospective teachers thought the teaching of child rights should be done in pre-school period with reasons such as contributing to the process of children's behavior developing, being people who know about their rights and who have the skill of defending themselves. At the end of this study, it was determined related with child rights that prospective pre-school teachers gave more narrow-scoped results than prospective primary school teachers. Related to the results of the aforementioned study, when the necessity of starting an education about child rights in the pre-school period is taken into consideration, it can be said that prospective teachers' perceptions about child rights should be developed. On the other hand, in their study they aimed to find out the attitudes of prospective pre-school teachers about child rights, they found that in general, prospective pre-school teachers' attitude scores about child rights were quite high.

In their study they conducted to find out prospective pre-school teachers' views and experiences about child abuse, neglect and violence and the prevention of these, it was found that few educators were trained about violence, child abuse and neglect. In this study, it can be seen that when compared with prospective primary school teachers, prospective pre-school teachers focused more on the right of children to be protected from every kind of bad actions. Starting from the aforementioned research findings, it can be said that both prospective teachers groups should be provided with qualified teaching processes about child rights and protecting children from abuse and neglect.

Based on the results of the study, it can be said that in general, prospective primary school teachers and pre-school teachers have similar perceptions about child rights. However, it can be said that the frame of perception about child rights point to a more limited area in prospective pre-school teachers. On the other hand, it is thought that both prospective teacher groups do not have enough awareness and perception about some rights within the participation and development right axis. At this point, it has to be taken into consideration that teachers have a critical role in increasing the awareness and developing the perceptions of students about their own rights. When this situation is taken into consideration, it is thought that it is extremely important and necessary for prospective teachers, who are the teachers of the future, should have enough awareness about child rights, comprehensive knowledge about the subject and behaviors suitable for this accumulation of knowledge. Within this context, it is thought that it is an important necessity for prospective primary school and pre-school teachers to associate child rights and child rights education with the subjects in their undergraduate lessons and in addition to this, it is necessary for them to take part in processes of research and project which consists of comprehensive and different partners on the related subject, to get at least one lesson about the related subject in education faculties, to increase their awareness about the mentioned subjects and to support the development of their perceptions development.

\section{References}

Akyüz, E. (2012). Çocuk hukuku. Ankara: Pegem Akademi.

Burlacu, F. (2012). Children's right to education. Euromentor Journal, 3(4), 126-136.

Büyüköztürk, Ş., Çakmak, E., Akgün, Ö. E., Karadeniz, Ş., \& Demirel, F. (2011). Bilimsel araşstırma yöntemleri. Ankara: Pegem Akademi.

Cevher, D. M. (2007). Suça sürüklenen çocuklar. In A. İçinde Solak (Ed.), Okullarda şiddet ve çocuk suçluluğu (pp. 19-35). Ankara: Anı Yayıncilik.

Clair, N., Miske, S., \& Patel, D. (2012). Child rights and quality education: Child-Friendly Schools in central and eastern europe (CEE). European Education, 44(2), 5-22. https://dx.doi.org/10.2753/EUE1056-4934440201

Creswell, J. W. (2013). Araştırma deseni: Nitel, nicel ve karma yöntem yaklaşımları (S. B. Demir (Çev. Ed.)). Ankara: Eğiten Kitap.

Demirezen, S., Altıkulaç, A., \& Akhan, N. E. (2013). “Children's Rights” according to primary school students. Educational Research Association the International Journal of Educational Researchers, 4(1), 39-52.

Dereobalı, N., Çırak Karadağ, S., \& Sönmez, S. (2013). Okulöncesi eğitim öğretmenlerinin çocuk istismarı, ihmali, şiddet ve eğitimcilerin rolü konusundaki görüşleri. Ege Eğitim Dergisi, 14(1), 50-66.

Dinç, B. (2015). Okulöncesi eğitim kurumuna devam eden çocukların ebeveynlerinin çocuk hakları eğitimi konusundaki görüşleri. Eğitimde Nitel Araştırmalar Dergisi, 3(1), 7-25. 
Doğan, Y., Torun, F., \& Akgün, İ. H. (2014). Okul öncesi öğretmen adaylarının çocuk haklarına ilişkin tutumlarının çeşitli değişkenlere göre incelenmesi. International Journal of Human Sciences, 11(2), 503-516. https://dx.doi.org/10.14687/ijhs.v11i2.2998

Dündar, H., \& Hareket, E. (2016). Türkiye'de ilköğretim hayat bilgisi ve sosyal bilgiler dersi öğretim programlarının çocuk hakları açısından incelenmesi. Manas Sosyal Araştırmalar Dergisi, 5(2), 85-103.

Ersoy, A. F. (2011). İlköğretim öğrencilerinin çocuk haklarına ilişkin algıları. İlköğretim Online, 10(1), 20-39.

Glesne, C. (2014). Nitel araştırmaya giriş (A. Ersoy, \& P. Yalçınoğlu, Eds.). Ankara: Anı Yayıncılık.

Hareket, E. (2015). Çocuk sosyolojisi bağlamında çocuk ve çocuk hakları kavramının gelişimi ve değerlendirilmesi. In L. İçinde Eraslan (Ed.), Farklı perspektiflerden çocukluk ve sosyolojisi (pp. 125-143). Ankara: Vize Yayıncılik.

Hareket, E., Çağlayan, K. T., \& Dündar, H. (2016). Çocuk haklarına ilişkin algı gelişiminde çocuk meclisi uygulamaları. The Journal of Academic Social Science Studies, 42, 445-463. https://dx.doi.org/10.9761/JASSS3098

Karaman Kepenekçi, Y., \& Baydık, B. (2009). Zihin engelliler öğretmen adaylarının çocuk haklarına ilişkin tutumları. Ankara Üniversitesi Eğitim Bilimleri Fakültesi Dergisi, 42(1), 329-350.

Karaman Kepenekçi, Y., \& Nayır, F. (2012). Çocukların ana babaları tarafından istismar ve ihmaline ilişkin sınıf öğretmenlerinin görüşleri. The Journal of Academic Social Science Studies, 5(7), 437-455.

Merriam, S. B. (1998). Qualitative research and case study applications in education. San Francisco: Jossey Bass.

Miles, M. B., \& Huberman, A. M. (2015). Nitel veri analizi (S. Akbaba Altun, \& A. Ersoy, Eds.). Ankara: Pegem Yayıncilik.

Neslitürk, S., \& Ersoy, A. F. (2007). Okulöncesi öğretmen adaylarının çocuk haklarının öğretimine ilişkin görüşleri. Eğitimde Kuram ve Uygulama, 3(2), 245-257.

Orkodashvili, M. (2013). Quality Education through Child-Friendly Schools: Resource Allocation for the Protection of Children's Rights (English version). Revista romaneasca pentru educatie multidimensionala Journal for Multidimensional Education, 5(1), 101-109. https://dx.doi.org/10.18662/rrem/2013.0501.07

Patton, M. Q. (2014). Nitel araştırma ve değerlendirme yöntemleri (M. Bütün, \& S. B. Demir, Eds.). Ankara: Pegem Yayıncilik.

Quennerstedt, A., \& Quennerstedt, M. (2014). Researching children's rights in education: Sociology of childhood encountering educational theory. British Journal of Sociology of Education, 35(1), 115-132. https://dx.doi.org/10.1080/01425692.2013.783962

Robson, C. (2015). Bilimsel araştırma yöntemleri (Ş. Çınkır, \& N. Demirkasımoğlu, Eds.). Ankara: Anı Yayincilik.

Tezcan, M. (2012). Çocuk sosyolojisi. Ankara: Anı Yayıncılık.

Tintor, A. M. (2013). Community resilience and the fulfilment of child rights in the family, school and community. CEPS Journal: Center for Educational Policy Studies Journal, 3(2), 71-91.

Uçuş, Ş., \& Şahin, A. E. (2012). Çocuk hakları sözleşmesine yönelik öğretmenlerin ve okul yöneticilerinin görüşleri. Adnan Menderes Üniversitesi Eğitim Fakültesi Eğitim Bilimleri Dergisi, 3(1), 25-41.

Yaşar Ekici, F. (2014). Öğretmen adaylarının çocuk haklarına yönelik tutumlarının bazı değişkenlere göre incelenmesi. Akademik Sosyal Araştırmalar Dergisi, 8, 66-77. https://dx.doi.org/10.16992/asos.417

Yıldırım Doğru, S. S. (2014). Yasal düzenlemeler. In S. S. İçinde Yıldırım Doğru (Ed.), Çocuk kakları ve koruma aile refahı ve koruma (pp. 1-39). Ankara: Eğiten Kitap

Yin, R. K. (2009). Case study research: Design and methods (4th ed.). Thousand Oaks, California: SAGE.

\section{Note}

Note 1. This research was presented as verbal statement in 15th International Primary Teacher Education Symposium (11-14 May, 2016), Muğla, TURKEY. 


\section{Copyrights}

Copyright for this article is retained by the author(s), with first publication rights granted to the journal.

This is an open-access article distributed under the terms and conditions of the Creative Commons Attribution license (http://creativecommons.org/licenses/by/4.0/). 